INSIGHTS INTO REGIONAL DEVELOPMENT

ISSN 2669-0195 (online) http://jssidoi.org/IRD/

2020 Volume 2 Number 4 (December)

http://doi.org/10.9770/IRD.2020.2.4(5)
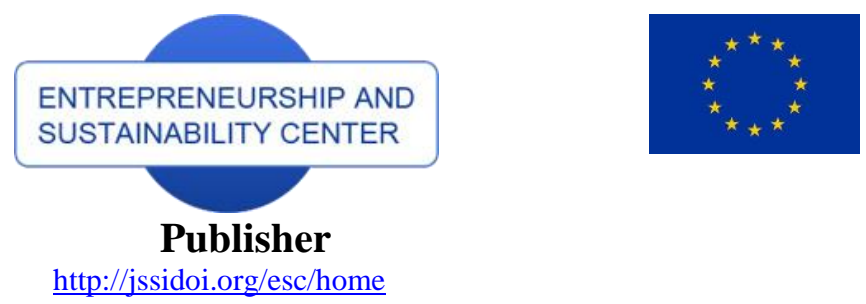

\title{
TOWARDS AN ONTOLOGICAL REASON LAW IN ECONOMICS: PRINCIPLES AND FOUNDATIONS
}

\author{
Francesco Vigliarolo ${ }^{1,2,3}$ \\ ${ }^{I}$ Catholics University of La Plata, Argentina, Street 25, between 47 and 48 streets, CP 1900, La Plata, Argentina \\ ${ }^{2}$ Chair free Economics system and Human Rights, National University of La Plata, Argentina \\ ${ }^{3}$ Centre Study of Sociology of work, Economics Faculty, UBA, Argentina \\ E-mail: fvigliarolo@gmail.com
}

Received 15 May 2020; accepted 10 October 2020; published 30 December 2020

\begin{abstract}
The objective of this article is to propose what can be called a law of ontological reason in economics as opposed to the law of supply and demand. To do this, it uses a phenomenological approach that interprets economics in terms of primary ideas. To this end, it's defined the ontological reason and the space in which it is built in order to introduce the concept of demand of rights and not of consumption. In this context, the relationship that underlies an ontological reason which presupposes a different behavior from that of the law of supply and demand is then described. According to this approach, it is claimed that the latter leads to structural problems. It subordinates the general identity of a country to the interests of individuals, as it focuses on maximizing personal utility that is unrelated to the creation of the rights of men and women living in a context that contains them in a relational way.
\end{abstract}

Keywords: economics; ontology; phenomenology; demand for rights

Reference to this paper should be made as follows: Vigliarolo, F. 2020. Towards an ontological reason law in economics: principles and foundations. Insights into Regional Development, 2(4), 784-801. http://doi.org/10.9770/IRD.2020.2.4(5)

JEL Classifications: A10, N01, P00

Additional disciplines: sociology; phenomenology.

\section{Introduction}

Why in economics is the law of supply and demand considered the main if not the only existing law that defines the behavior of economic actors and goods' value? Is it possible that this law has serious problems in itself, that is, it does not correctly describe behavior if the objective is the general identity of countries that exists as a potential ontological dimension that cannot be reduced to a sum of individual interests? Furthermore, why did mathematical reasoning monopolize the spaces of economic decisions? Why can there be no other motivation to act, and all of them are based primarily on positivist mathematical logic? And if so, it is possible to get out of this paradigm that leads to living everything in terms of utility, even the ideas of what is considered important and the 
INSIGHTS INTO REGIONAL DEVELOPMENT

ISSN 2669-0195 (online) http://jssidoi.org/jesi/

2020 Volume 2 Number 4 (December)

http://doi.org/10.9770/IRD.2020.2.4(5)

same workforce that should have a life in its own and, therefore, a value potentially linked to defining the ontological elements of a people?

Based on these questions, the paper proposes what we call an ontological reason law in economics. A relation that tries to describe the possibility of the economic system to achieve the ontological conditions of a community that cannot be subject to the law of supply and demand because this only explains the maximization of personal utility in conditions of fluctuations of prices and quantities based on mathematical reasoning.

The analysis is based on the assumptions of economic phenomenology, a branch of phenomenology that studies economics in the formation of its primary ideas and, therefore, in terms of possible ontological reason, that is what is considered important for people through the relationship between noesis (intention of the subject) and noema (object) which is always an idea, a concept to be interpreted (Vigliarolo, 2019). Therefore, the ontological reason implies a relational dimension that constitutes a potential identity dimension, between people and the context (natural) and among the same people (social). By definition, it supposes the existence of common values that cannot be managed as an individual utility dimension based on the law of supply and demand. Before exposing this, are proposed the basics of economic phenomenology, the process of reducing goods and services into primary ideas, the presence of the general and particular characteristics that make up ideas as a presupposition of the union between individual freedoms and general identity, the spaces where these priorities can be built, that is the meso-economy, where what is called a demand for rights as opposed to that of consumption is constituted.

\section{Economic phenomenology: a theoretical approach for observing the ontological reason of economics}

Economic phenomenology is the branch of phenomenology that aims to study the economy in the formation of its primary ideas, which contribute to the creation of the structure and vision of life of a country, a society, starting from the pure consciousness that opens up to the world, interpreting the relationship between noesis and noema. In this direction, it studies the coherence of economic systems with respect to these ideas considered priority in human consciousness and how these can represent the structures of an ontological reason that allows the implementation of what we call the Being of societies in the world (Vigliarolo, 2019).

For these reasons, economic phenomenology observes and interprets what we call the possible "ontological reason" of societies as opposed to utilitarian reason, the result of a positivist vision focused mainly on individual interest and on the mathematical logic that presupposes an increase in monetary value without limits that leaves out important questions such as: what kind of world do we want? What is important for our societies?

Starting from this premise, it is proposed that the economy can be understood through a "demand for rights" and not of consumption, which arises from what is considered important as ontological elements that can potentially be present in everyone. For example, the use of food implies the idea of eating. We don't have to wait until we are hungry to incorporate it into social organization, because in our consciousness we already know that it is essential to live. Therefore, if considered important for everyone, it represents a right or a value because it is necessary for the whole society. Healthcare facilities, education, etc. The idea of health care, training and so on. Therefore, the phenomenological approach always observes the social conscience, which is behind the economic system and not the single individual. All this implies that the rights of men and women living in a society, as phenomenological aspects of individual and social being, are considered rights when they are considered potentially part of everyone's identity. This means that some rights, although they are something that arise (as a potential structure) with people, also depend on the conditions that are installed in society and, first of all, in the economic system to have their full realization. Without roads or means of transport, our right to travel would be limited. Without a 


\section{INSIGHTS INTO REGIONAL DEVELOPMENT}

ISSN 2669-0195 (online) http://jssidoi.org/jesi/

2020 Volume 2 Number 4 (December)

http://doi.org/10.9770/IRD.2020.2.4(5)

home, our right to have a home and living intimately with our family would not exist. Without manufacturing, many phenomenological aspects of our way of being, such as sitting, sleeping in a bed, drinking in a glass, etc. they would be limited and affect our social rights. Without being able to go to school and receive instruction from teachers, our right to education would also be limited. And so on for many other aspects that can be added and that are part of what can be called the ontological reason for social life that emerges from the relationship with materiality and from what men and women who live in a context define as such; which therefore is always a concept, an idea, which can be interpreted and to which a degree of importance can be given.

\section{$\underline{\text { General and particular characteristics }}$}

These ideas can be defined through general and particular characteristics. Generals are, for example, the idea of eating, the idea of having a health system, the mobility, the functions that derive from the production of manufactures, or having a house where living with the family, etc. Particular are the ways in which these ideas are realized, that is the specific production of goods and services, specific foods, roads, cars, buses, trains, houses, etc. to implement these general characteristics. That's allow us to dissociate the economy form the materiality and affirm that not all that is tangible is real, as positivism asserts.

Therefore, society can define what is important, its vision of life that determines from all the ideas considered essential, if they are potentially valid for everyone or if they are in conflict with each other; that's what we call ontological reason. For these reasons, an individual economic action, if it wants to pursue a community ontological reason, must always tend to build a general vision in which to seek its coherence (as we will see later with some standard reports). For example, a company is born, lives and always develops in a context made of relationships with others and with the surrounding environment. It can produce goods that are useful for social life, it is a source of wages that are needed by families to satisfy their present and future necessities (when they can save) and refeed the same company again. It is subject to a national and international legal rules within a political and social order that defines and contains it. It is part of a social and natural context which, if not respected, will cause serious damage to the community. It is made up of workers with a human and social history who live in a own biographical dimension. But, first of all, they are bearers of relational ontological needs at a specific time. If a company acts only according to the law of supply and demand that seeks only commercial interests, it does not necessarily contribute to the development of an ontological reason. Instead, if it builds a "we" with the society, strengthens the context and its identity at the same time. Together with other actors, it can contribute to the creation of a general identity from which potential rights are generated. When all these are linked together, we call them "relational and constitutive rights" of a country. In other words, they are common values represented by goods and services as necessary tools of social being that contain an interpretable intention and, therefore, an intelligibility of the economic system in terms of an ontological reason and not only of maximization of profits. 
INSIGHTS INTO REGIONAL DEVELOPMENT

ISSN 2669-0195 (online) http://jssidoi.org/jesi/

2020 Volume 2 Number 4 (December)

http://doi.org/10.9770/IRD.2020.2.4(5)

\section{The method of economic reduction in ideas}

The observation is based on the interpretation of the intentions that animate the relationships between people and objects. This intention is part of the formation of the process of knowledge that takes place in each man's own biographical situation and is intersubjective by definition (Schültz, 1962). This allows us to interpret goods and services in terms of primary ideas that can thus be interpreted by consciousness giving them a degree of importance. In this scenario, the economic reduction interprets the social conscience behind the economic system and allows us to understand if it responds to priorities considered to be such, what we have called ontological reason.

Then, we can ask ourselves: how can we observe the dimension of social consciousness which animates an economic system that presupposes individual actions? How to interpret the primary ideas of an economic system through the intersubjective knowledge and relationship with materiality?

Starting from these questions, we define phenomenological reduction in economics, the transformation of economic facts into "primary ideas" through the process that leads to its extreme consequences a process, a relationship through their intention. By intention, we mean the deep motivations of people that arise from interpreting their life plans, how they live, why they use goods and services, the meaning they give to things and so on. In Heidegger's terms, who puts the emphasis on Being and ontology, it means describing what he calls the "structure of everyday life," or "being in the world," and what he defines intentional projects. To understand true intentionality, it is necessary to define understanding the deep meaning of human experiences in their daily life. This intentionality is more fundamental and the one that makes directionality possible from scientific knowledge. In other words, behind the relationship between people and between them and materiality we can reduce the primary ideas that animate the social essence and determine the thinking structure of economic systems. For example, the idea of eating, living in a house, studying, the different meanings that arise from the use of manufactures, etc... If all people may need to have a home, move, education, health, ... at the same time and at a specific time, if they are not in conflict, they can be considered essential for a society and not for an individual. Hence, they can be considered values and orient the economic system in terms of being. If these are necessary and potentially universal, they can also be defined as rights (relational and constitutive rights of a society for a given historical moment). In this way it is observed whether the real intentions of systems, through relationships, can coexist and how they depend on the processes and organization of social life. Thus, the reduction of the economy to ideas presupposes interpreting the experiences of people in their daily lives, that is, what they buy, what they produce, where they invest, etc. but also what they consider important.

The reduction can be done a priori, simply by interpreting the idea that arises from the intention observed directly through social relations and with objects (experiences in everyday life); or, a posteriori, by analyzing over time what the intention actually produces at a general level. The two dimensions (a priori and a posteriori) can be fed and, since it is impossible to reach the end of time, in the absence of stable or present data, the ideas underlying a behavior are subjectively brought to extreme consequences in a subjective way. Therefore, a subjective interpretation of intentionality (economic reduction) is determined with progressive degrees of objectivity; for this reason, it is stated that economics is a social phenomenon and, as such, it is not an exact science according to mathematical laws. In fact, the law of supply and demand, which is based on a direct relationship with the maximization of profit, in its extreme consequences does not allow us to understand what kind of ontological dimension develops. The noematic dimension cannot be interpreted directly as behavior because the absolute value of a good or service changes based on fluctuations in quantity. Which ontologically makes no sense, as we will see below. 
INSIGHTS INTO REGIONAL DEVELOPMENT

ISSN 2669-0195 (online) http://jssidoi.org/jesi/

2020 Volume 2 Number 4 (December)

http://doi.org/10.9770/IRD.2020.2.4(5)

\subsection{Some standard relationships}

In the next frameworks are proposed some standard relationships can be observed which allow to interpret the coherence of the relationships between the economic actors with respect to a shared human and social values, starting from their intentions toward the relation with the others and goods (see Figure 1).

Complete correspondence between visions and goods based on exchange according to need and reciprocity.

\begin{tabular}{|c|c|}
\hline \multicolumn{2}{|c|}{ Set of common priorities considered as such by a society } \\
\hline $\begin{array}{c}\text { Social actor 1 } \\
\text { Good }\end{array}$ \\
$\begin{array}{c}\text { Money a good contains an idea related a need } \\
\text { (no negatives externalities) } \\
\text { Money }\end{array}$ \\
It produces a right according to the vision. \\
Being is defined
\end{tabular}

Figure 1. Type of extreme relationship.

The first panel shows that the two actors have an intention that contains a "potentially coherent relationship" directly interpretable. On the one hand, the action is oriented towards a defined object (it has a direct relationship between noesis and noema), and both want what the other offers. On the other hand, the intentions do not contradict each other or with the common space (for example, it has no negative externalities with the environment) and the ideas behind the goods are not in conflict. In this scenario, the two actors expect the other to behave according to principles that do not contradict each other and create a common conscience that guides socio-economic relations, regardless of whether it is a market or a public economic system. We can deduce the primary ideas that guide the organization of the system and the management of resources that feed the progressive phases of consciousness in continuous evolution. Progressive levels of consciousness are determined for various goods and services considered necessary to exercise certain rights. This is why we talk about relational and constitutive rights, which arise from the relationship with society and constitute it at the same time. This does not mean that they share the same values, but that priorities do not contradict each other (see Figure 2). 
INSIGHTS INTO REGIONAL DEVELOPMENT

ISSN 2669-0195 (online) http://jssidoi.org/jesi/ 2020 Volume 2 Number 4 (December)

http://doi.org/10.9770/IRD.2020.2.4(5)

Partial correspondence, with the absence of complete common vision and the presence of negative externalities.

\begin{tabular}{|c|}
\hline \multicolumn{2}{|c|}{ Set of common priorities considered as such by a society } \\
\hline Social actor 3 \\
Invest in asset \\
Good \\
with high negative externalities \\
or \\
commercial goods whose use does not produce \\
something \\
that satisfies an essential need \\
$\square$
\end{tabular}

Figure 2. Typology of extreme relation.

The second panel shows a partial relationship in terms of common vision. For actor 3, money is not used to directly purchase goods that satisfy needs, so it does not produce, as we have said, an interpretable concept (the observable ontological dimension is partially lost). Furthermore, it is an accumulation tool that is invested in other securities and, at the same time, has negative externalities. It can be said that only a fraction of the money will be used to create an ontological dimension. The remainder is used to augment a system in which neither actor operates with an observable phenomenological relationship (see Figure 3). 
INSIGHTS INTO REGIONAL DEVELOPMENT

ISSN 2669-0195 (online) http://jssidoi.org/jesi/ 2020 Volume 2 Number 4 (December)

http://doi.org/10.9770/IRD.2020.2.4(5)

Partial correspondence, with no common vision and speculation.

\begin{tabular}{|c|c|}
\hline \multicolumn{2}{|c|}{ Set of common priorities considered as such by a society } \\
\hline Social actor 5 \\
Buy another good \\
(without negative externalities) \\
Produces a right if you define your being according \\
to the (essential) vision
\end{tabular}

Figure 3. Type of extreme relationship

In this third panel, we are also faced with a partial ontological relationship, but for other reasons. An actor uses the relationship only to improve his personal interests and buys to sell and invest in financial markets without an observable noematic dimension. Bringing it to its extreme consequences, prices are formed through the laws of supply and demand on stock exchanges, which remove the value of goods from real production factors because profit depends on the financial income that is produced and this has different paths from production. There are speculative phenomena that allow to buy without having the real value of the securities. Then, non-real nominal values are installed, depending on the monetary fluctuations that allow large capital gains, ultimately unrelated to real size. This is how the economy becomes financial and nominal, that is, in phenomenological terms, it loses its ontological observable potential. We could say that this process is one of the standard relationships that phenomenologically causes the breakdown between society and the economy and, at the same time, the same systems, because the declared liquidity does not exist. This could also be read as a low level of social awareness of individuals with respect to the type of social order they are building; in terms of Stiglitz (2010), is due to the behavior of economic actors (Figure 4). 
INSIGHTS INTO REGIONAL DEVELOPMENT

ISSN 2669-0195 (online) http://jssidoi.org/jesi/

2020 Volume 2 Number 4 (December)

http://doi.org/10.9770/IRD.2020.2.4(5)

Total lack of correspondence, with absence of common vision and presence of high negative externalities.

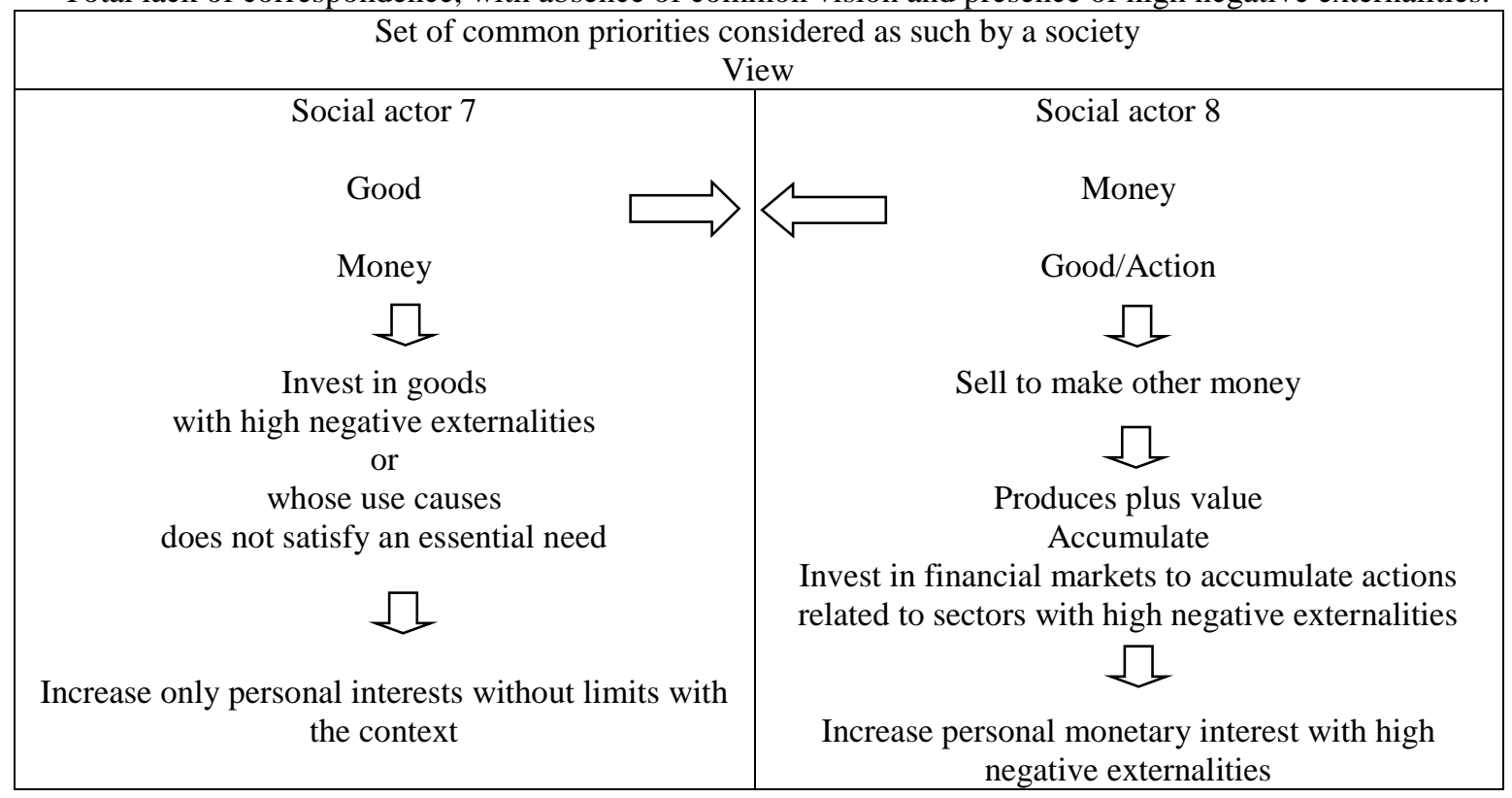

Figure 4. Type of extreme relationship

The fourth panel, represents a type of extreme relationship which, according to this observation, offers more closely for example the causes of the financial crises that we have observed in recent years. The type of relationship contains an almost definitive loss of phenomenologically observable ontological reason. It represents a potential situation of global crisis if adequate measures are not taken to protect universal ontological elements for all. For example, we have some concrete cases such as the health systems in Europe, real production in developing countries or the presence of goods essential to life such as food in poor countries. Not to mention the negative externalities of the economic system of the industrial countries, the result of the unlimited exploitation of resources. All this due to transactions based on the law of supply and demand that transform everything into monetary interest with no social horizon.

\section{Some structural limits that underlines the law of supply and demand and mathematical reasoning}

The law of supply and demand is based on the variation of two variables, quantity and price. It is assumed that if the quantity of the supply of goods and services decreases, the price value of the same increases. We can have goods whose value is defined on quantity and price variation, based on behavior, such as Giffens or luxury ones; values are not defined on the basis of the meaning they have or the function they perform and whether they are considered important to life. For these reasons they can also be defined all as consumer or commercial goods, whose main intention is to increase monetary interest (which are the most important microeconomic variables of classical economy). The first observation is that, in its extreme consequences, this law treats all goods equally, as if they were all instruments for maximizing the self-interest that ends up being, the increase in monetary gain. Secondly, relationships between people are reduced to "using" the other to achieve a personal goal and not to build a relational identity. It distances people from a common social construction. 
INSIGHTS INTO REGIONAL DEVELOPMENT

ISSN 2669-0195 (online) http://jssidoi.org/jesi/

2020 Volume 2 Number 4 (December)

http://doi.org/10.9770/IRD.2020.2.4(5)

According to the schemes seen above, this law will never allow the economy to have a social behavior oriented towards the search for goods and services that respond to a relational ontological dimension (common priorities). It is the market that defines the priorities and value of goods according to fluctuations in quantity and price. So, it does not allow us to interpret the economy in terms of ontological intelligibility, because in their primary intention market players tend to maximize monetary values and not produce goods and services that respond to needs. This produces a society of interests, that is, it transforms passions, vocations, feelings, ... into interests (Hirschman, 1979) accentuating the separation between ontological reason and the economic system. In case of special needs or crisis of extreme scarcity of resources, the underlying behavior cannot provide answers because the relationships, in their extreme consequences, do not meet in common values but only pursue interests.

Below, we propose how to solve this situation and the law of ontological reason that is proposed, on the basis of other hypotheses and behaviors than those underlying the law of supply and demand. Before doing it, we can say that from the typed relations seen above, when the economy is guided by relations that do not realize a common ontological vision, which by definition is relational, it risks imploding because it progressively destroys the real basis on which society is founded. For these reasons, as we have seen, that depends on the vision of life and relationships or the social capital that underlies an economic system. In this direction, we propose the concept of ethical social capital which underlies the law of an ontological reason.

\section{Ethical social capital}

In order to build an ontological reason, the existence of an ethical social capital is necessary. To understand what we are referring, we introduce the concept of "social capital". Starting from the collectivist extreme -using the terms of Katz and Lazarsfeld (1955)- ended up having an individualistic approach -according to Bourdieu and neoliberal concepts-, which today can be seen as a resource through which individuals can profit opportunistically. In fact, generally, this type of capital is defined as the system of relationships that underlie contemporary capitalist societies. Seen in this way, the meaning of social capital approaches the notion of "means" according to the theories of the sociology of action; and in the clearly Durkheimian collectivist meaning it does not differ much from the concept of "dynamic density", ie the relative weight of the organizations/networks of a society. All this, however, tells us nothing about the purposes, the intentionality, pursued by this type of capital. Anyway, it can be bonding, exclusive and working for families and friendly bonds; or bridging, inclusive and capable of creating bridges to each other. In the first case, we have the families and group power lobbies or mafia too, as bonding social capital type; in the second case, we do not have information on common values necessary for a primary socialization. It means, in its extreme consequences, that everybody can act only based on individual freedom. This, in fact, despite being inclusive, tells us nothing about the possibly "universal" collective construction with respect to the type of world it tends towards, in the sense of whether it includes elements that are potentially possible and necessary for everyone's life. It is in this context that the concept of ethical social capital is introduced (Vigliarolo, 2011), because it proposes that there needs a nucleon of common values. In this scenario, when relationships are guided to promote common values and considered necessary and potentially universal to define an intersubjective identity that surpasses the individual and contains it at the same time, we can speak of ethical social capital. That is, we can define it as: "The set of free actions and relationships guided by cultural meanings conceived as values - potentially universal, reciprocal and necessary - that feed a common identity in which individual freedom and general interest are strongly related and tend to build an ontological reason that can guide the economy "(Vigliarolo, 2012). In this case, relationships presuppose a "positive" expectation, defined on the basis that everyone expects that others also have the same behavior with respect to a core of common values considered necessary for collective life. All this, when transferred into economics, determines what we call the demand for rights of a population or the whole world. In continuation, we see how. 
INSIGHTS INTO REGIONAL DEVELOPMENT

ISSN 2669-0195 (online) http://jssidoi.org/jesi/

2020 Volume 2 Number 4 (December)

http://doi.org/10.9770/IRD.2020.2.4(5)

\section{The meso-economy}

According to the architecture we proposed, in economy we can define "intentional variables" which relations with object allow to observe the primaries ideas, in terms of noesis and noema. For example, "investments" when are directed to "production of good and services" can be interpreted in term of ideas and priorities. On the contrary, when it's oriented to other financial variables without relations with productions, lose the human and social intelligibility. For these reasons, we can define the following as the main intentional variable: investments and wages deriving from the workforce. Without labor there is no possibility of production. On the other hand, we can have the secondary ones, such as: savings, interest tax, etc. Because they depend on the former. Every interpretation needs production, the noematic dimension and the relationship between people. But not all production is linked to people's rights. For example, we cite a 1980 study by Daly and Cobb which analyzes how in the 1970s, in the United States, GDP increased and ISEW decreased. This meant fewer rights for people and a greater concentration of resources in a few people; o an economy that increases production for nominal financial purposes, remember that $95 \%$ of the financial value is not related to goods and services; or the increase of new poverties due to market dysfunctions and not due to lack of resources. Or the fact that a country can grow with the arms industry, which means a vision of a life of war that not all people would like. Recalling the standard relations described above, in other words, we can say that not all economic relations lead to the exercise of rights and, at the same time, not all financial values can be interpreted. It depends on the ability to direct investments towards that production whose ideas can be interpreted and considered important for the whole society. To this end, a social pact is necessary which represents the set of life priorities of a people at a given historical moment.

In economic terms, this pact can be studied and constructed in an intermediate dimension, between the micro and the macro economy. A space that goes beyond the individual interests of the micro and the positivist mathematical variables of the macro, such as the public-GDP deficit. This space allows to give intelligibility to the system that is inspired by common priorities defined subjectively through the interaction of social partners who carry forward an ethical social capital as ideas/values. It can be called "meso-economics dimension". It allows the definition of strategic sectors, giving them a social meaning based on the function they perform for progressive levels of rights (demand for rights). In other words, it defines the set of values (social, environmental, etc.) that a country or a society must promote in order to affirm its ontological reason.

It can be made up of social movements, civil society, trade associations, trade unions, companies, organizations, etc. Which together with the State define strategic priorities starting from the primary ideas that define a demand for rights to which strategic productive sectors correspond in order to implement it. In this scenario, we can define the Ontological Strategic Growth Index (OSGI). (See formula below and Table 1)

ICE $=\quad$ values of goods and services related to strategic sectors thought as rights (it includes related financial values and costs of social and political institutions)

values of total goods and services total

(includes all financial values and costs of social and political institutions) 
INSIGHTS INTO REGIONAL DEVELOPMENT

ISSN 2669-0195 (online) http://jssidoi.org/jesi/

2020 Volume 2 Number 4 (December)

http://doi.org/10.9770/IRD.2020.2.4(5)

Table 1. Ideas with general and particular characteristics

\begin{tabular}{|l|l|lr|}
\hline \multicolumn{3}{|c|}{ Economic in "primary ideas" } \\
\hline $\begin{array}{l}\text { Generals characteristics (social } \\
\text { pact, meso economy) }\end{array}$ & \multicolumn{1}{|c|}{$\begin{array}{c}\text { Particular characteristics } \\
\text { (individual freedom) }\end{array}$} & \multicolumn{1}{c|}{$\begin{array}{c}\text { Eventual } \\
\text { conflicts/externalities }\end{array}$} \\
\hline The idea of eat & Different types of food & $\begin{array}{l}\text { Environmental and } \\
\text { impact }\end{array}$ & social \\
\hline The idea of education/Formation & $\begin{array}{l}\text { Different subjects, topics and } \\
\text { different levels and degrees of } \\
\text { teaching }\end{array}$ & & \\
\hline The idea of moving & Different ways and means for moving & $\begin{array}{l}\text { Environmental and } \\
\text { impact }\end{array}$ & social \\
\hline The idea of wealth & Different services & $\begin{array}{l}\text { Environmental and } \\
\text { impact }\end{array}$ & social \\
\hline $\begin{array}{l}\text { Different ideas tha correspond to } \\
\text { life functions such as sleeping in a } \\
\text { bad, drinking in a glass, etc. }\end{array}$ & Different manufactures & $\begin{array}{l}\text { Environmental and } \\
\text { impact }\end{array}$ & social \\
\hline $\begin{array}{l}\text { The idea of having a home to live } \\
\text { in }\end{array}$ & Homes, building, ... & Etc. \\
\hline Etc. & Etc. & \\
\hline
\end{tabular}

\section{The law of ontological reason}

According to what we said, we can call a "law of ontological reason" the relationship that allows to observe and describe the functioning of the system in terms of the production of tools (noema), in order to lead to the exercise of the rights considered as such for a society in a meso-economics dimension (noesis). It depends principally on the sectors through which the direct intention of the actors can be interpreted, i.e. investment and wages. With the first, materiality is transformed; with the latter the resources are oriented to satisfy needs, etc. and they represent the way to feed again production. Using the above method, we can have two types of systems. The first, based on demand and supply law, that tends to balance through the fluctuations of price and quantity as we exposed; the second, which tends to balance between production and necessity/priorities. In this case, the prices depend on production factors and does not increase in case of scarcity of resources, otherwise they lose their social intelligibility.

In order to understand it, we can expose the following scenario. Suppose that some goods have a price $\mathrm{X}$ in a situation of quantity $\mathrm{Q}$ and elastic demand. If the demand for the goods increases, according to the law of supply and demand, the price increases. This means that the price reduces the purchasing power of families and reduces their range of access to rights with the same wages. At a certain point, families cannot buy more and companies keep unsold goods or they can sell them later with different prices that do not respond to the need that arose at a given moment. The behavior, in this case, only tends to increase the profit of those who sell the goods.

If, on the other hand, the price remains the same, families will buy more goods at the same price and the company can achieve an economy of scale based on production by also increasing profits. A maximum point is reached when the profit is related to production and not to price and quantity fluctuations. The behavior responds to the expansion of an ontological situation and not to the maximization of profit. Furthermore, if the prices do not allow the maintain the purchase power, in the short time, the company loses profits due to the lack of sale and a relationship identity is lost.

In the second case, we speak of responsible behavior (or communitarian ethics) according to the social capital that we have seen, because it allows the two actors to create a "relational right" and maintain a common vision. The 


\section{INSIGHTS INTO REGIONAL DEVELOPMENT}

ISSN 2669-0195 (online) http://jssidoi.org/jesi/ 2020 Volume 2 Number 4 (December)

http://doi.org/10.9770/IRD.2020.2.4(5)

two actors have strengthened, they can subsequently invest their time, knowledge and resources in other activities, allowing the economy to expand permanently starting from real capabilities. In the other scenario, everything is transformed in interests where one wins and the other loses because of the law of supply and demand that lose the value dimension of life. At the beginning one actor is strengthened in a situation of temporary advantage, but in the long term the whole context is weakened and the same actor too, because wages are reduced and can't buy anymore.

If we suppose another scenario in which the resources are limited and there are no possibilities to increase more productions, we are in front another choice in base to the objective. In this problem, Walras (Vuotto, 2006:11-66) come in our help.

If we hypothesize another scenario in which resources are limited and there is no possibility of further increasing production, we are faced with another choice that assumes its right logic based on the objective. To deal with this problem, Walras (1896, in Vuotto, 2006: 11-66) comes to our aid. The author of the famous economic balance, in an article (The science of social justice, 1896) deals with the problems of the economy and social justice, contrasting materialism and spiritualism. It rightly distinguishes two types of organizations, the first acting for social values, the second for economic profits. Organizations that act for social values are guided by spiritualism, or by right, placing man in the foreground. The second typology pursues the material objective by subordinating human life to wealth. But Walras affirms that "if man's work produces wealth, it is already not about man's wealth, but the same man". It cannot be dominated by materialistic logics but rather by logics relating to being, that is, right comes before materiality.

Therefore, in situations of extreme need for goods, the right to live in order to be, must prevail over the materialism, because without men and women, there is no possibility of continuing life. In this way, goods and services in extreme scarcity must follow other criteria, those that make it possible to implement the right to life and not to increase profits (to which the law of supply and demand responds).

Is it possible to put everything that has been said so far into a formula with economics intentional variables? In theoretical, assumption society ideas/values have to be expressed in production of good and services (demand of rights).

$$
\mathbf{S m}=\mathbf{P m}
$$

The principle intencional variables toward production are: investment and workforce. If all production $\mathbf{P}$, depend on workforce, WF, and Investment, I, other factors, $\mathbf{Z}$, we have:

$$
\mathbf{W F}(\mathbf{m})+\mathbf{I}+\mathbf{Z}=\mathbf{P}(\mathbf{m})
$$

If we assume that wages value depends on the $\mathbf{B}$ prices that define the real purchasing power and it has to contain a percentage of savings $\mathbf{E}$ necessary for the expansion of the system considered to be in constant evolution, we can replace $\mathrm{L}$ with $\mathrm{L}(\mathrm{B})+\% \mathrm{E}$ (that is, the real potential cost of money related to production value), we have:

$$
\mathbf{W F}(\mathbf{B}+\% \mathbf{E})+\mathbf{C}+\mathrm{Z}=\mathbf{P}(\mathbf{m})
$$

It means that only investments (capital, work, etc.) linked to priorities considered as rights (meso-economic goods and services as ideas) make the system expand according to a potential ontological direction; it means interpretable investment in ideas. 
INSIGHTS INTO REGIONAL DEVELOPMENT

ISSN 2669-0195 (online) http://jssidoi.org/jesi/

2020 Volume 2 Number 4 (December)

http://doi.org/10.9770/IRD.2020.2.4(5)

$\underline{\mathbf{S m}}$ is the set of values and principles considered by society to be objectified through goods and services interpretable through phenomenological approach in a meso-economics dimension.

$\underline{\mathbf{P m}}$ is the production of ontological or strategic goods at a given moment, defined at a meso-economic level. These are goods and services that directly or indirectly determine the identity of societies in terms of "priorities" in constant evolution, the value of which is linked to production and not to trade. Production depends on local, territorial, human and social vocations, on the skills acquired over time (workers' knowledge), etc ... but also and on the investment capacity of producers/entrepreneurs and the State. To be as representative as possible of ontological reason, it must be as pluralistic as possible because it responds to the process of knowledge formation which is intersubjective by definition. In other words, the more pluralistic the productive process, according to the different roles and functions, the more representative is the ontological reason of a society.

$\underline{\mathbf{C}}$ all private and public resources transformed in production and cost of institutions related. It on the training system and on the "wisdom" accumulated over the years by the workers, what Hegel called the true economic capital.

$\underline{\mathbf{W F}}=\mathbf{B}+\% \mathbf{E}$ are the value of wages permanently linked to prices and which contain a percentage of savings necessary for expansion. Wages must contain a defined percentage of strategic savings that families direct in the future in strategic sectors linked to rights.

$\underline{\mathbf{B}}$ are the prices of goods and services whose ideal conditions are determined by the company's ability to achieve its economy of scale, albeit in a situation of non-rigid demand. Under these conditions, the maximum profit is based on the workforce and capital and not on commercial operations or fluctuations due to supply and demand.

$\underline{\mathbf{Z}}$ are other aspects related to the context, such as distances, technology, environmental limits, social ethical codes, ontological priority coefficients related to strategic sectors, infrastructures, public goods, etc.

This relationship shows that the system creates ontological priorities only if there is a constant relationship between workforce, investment and production linked to the priorities of life. If we think that today the economy, through the process of economic financialization, registers $95 \%$ of financial values without relation to production, we assume that this relationship is no granted. This means that the economy today, as it is conceived, does not allow to reach an ontological reason of the peoples.

For this to happen, a different behavior is required, as we have seen, in accordance with Stiglitz said too, when he talks about the agency of economics actors (Stiglitz, 2010). But it is also necessary, and fundamentally, a collective institutional and social construction based on an ethical social capital that permanently imprints the priorities of life in the economy with norms, policies, priorities, that is, a stratecic mesoeconomic dimension. Otherwise, the economy tends only to represent a crematistic dimension (personal interest) and not to allows to manage the resources for the promotion of the "home", a specific context (ie the true function of the economy).

If there are any alterations between the described variables we have high chances that the system does not respond to a vision of community life but to unstable mechanisms that lead the system to permanent crises. For example, the active mesoeconomics tax of interest of money can't be incoherente with saving capability of wages. The maximum monetary benefits depend on achieving economies of scale based on the increase in production linked to needs through the workforce and the investment (capital, work, time, etc.) that generat goods and services with added value. This is called the ability of the economy to carry out an ontological reason.

Some implications are:

- The intelligibility of an economic system is based on the existence of primary ideas that must be implemented in practice to be objectified (pure reason is transformed into practical reason) by permanently constructing those "historical" answers and a vision of life.

- There is a minimum level of investment necessary for the activation of structural changes and this depends on the ability of countries to react to their situation of need or crisis. The ability to react depends on the awareness of what is important to people and on its need to make it happen.

- Firms make the most profit in relation to their economy of scale and when wages are a direct and proportional relationship between capital and prices.

- If capital is accumulated, the identity dimension of production is lost. In other words, in a capitalist system that orients its intention only to the accumulation of capital, the intention with objects is lost and can no longer be interpreted in terms of ontological reason. In other words, it loses the dimension of interpretable social consciousness and the possibility of achieving priorities, which happens with the law of supply and demand which is not linked to an identity dimension but to the opportunity for personal profit. 
INSIGHTS INTO REGIONAL DEVELOPMENT

ISSN 2669-0195 (online) http://jssidoi.org/jesi/ 2020 Volume 2 Number 4 (December)

http://doi.org/10.9770/IRD.2020.2.4(5)

- We can distinguish two types of capitalism, that which accumulates and that which invests in strategic sectors for human and social life. If there are no investments in ontological goods and services, society cannot develop its ontological reason which does not depend on the law of supply and demand.

Being the production and being of constantly evolving societies we speak of circular and progressive equilibrium. The union between freedom and common interest occurs in the union between particular characteristics and general characteristics. The former concretely realize the latter, they can be guided by individual freedoms which must build the general characteristics of ideas. For example, the idea of eating as a need for all, presupposes the production of food, that is general characteristic; the type of food that is produced, is freely defined by the actors, that is particular one. The same for mobility, the type of instruments depend on the free and individual initiative.

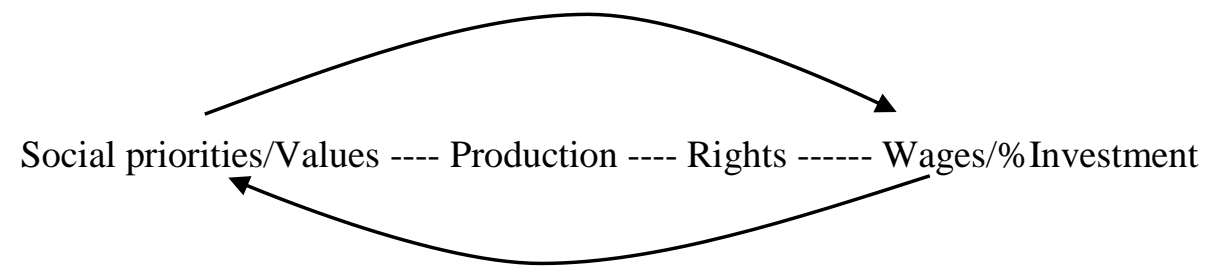

Figure 5. Circular equilibrium situation

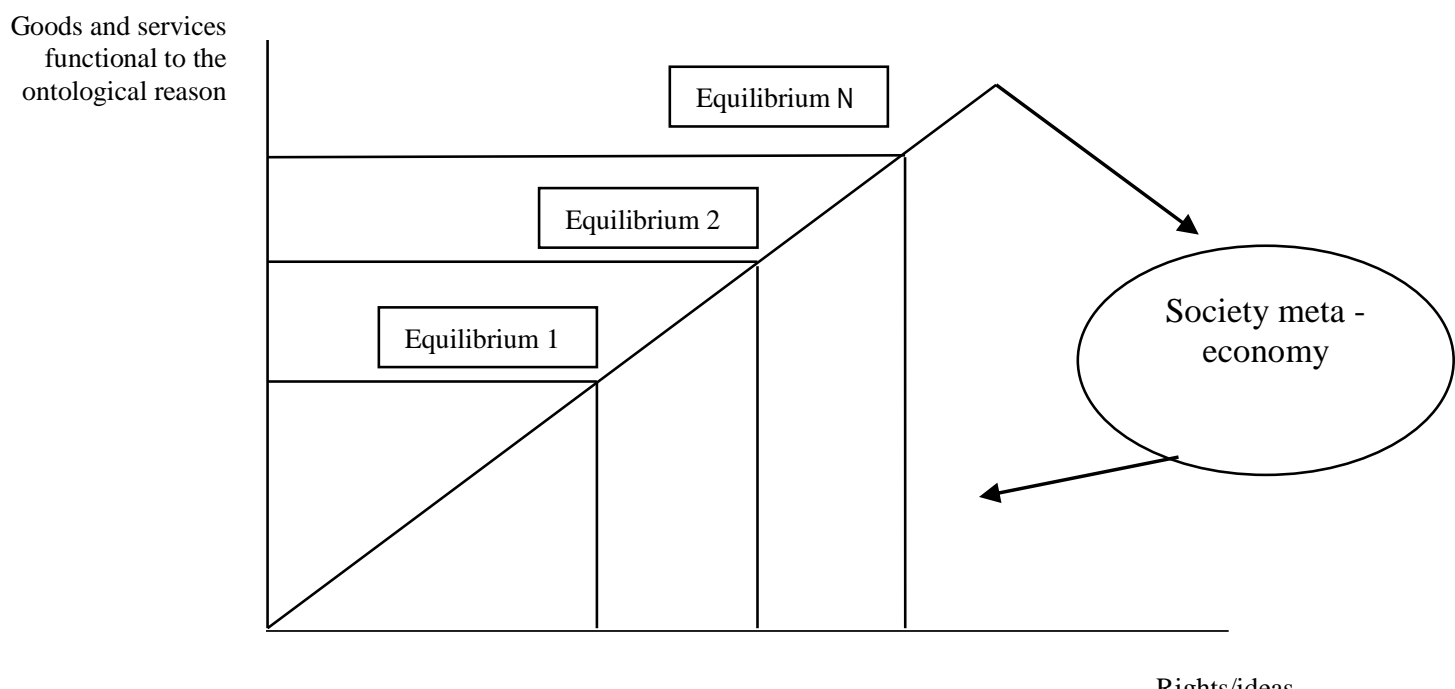

Figure 6. Graph of aggregate demand of rights for different levels of equilibrium 


\section{Conclusions}

Economics, which originated in the ancient world as a field of ethics, has lost its normative dimension (Keynes, 1891) due to the law of supply and demand; this implies that each actor seeks his own individual interests without building a relationship that carries forward a relational identity that can be interpreted in ontological terms. All this is accentuated with the classic system. Thus, more than two hundred years of classical economics have transformed the economic sciences into the sciences of individual opportunism and have made it lose its communitary ontological reason.

In fact, the foundations of classical economics describe only one type of behavior, which according to these pages is primitive to the construction of the "we" of a community. Classical economics is, therefore, a primitive science that does not take into account the intersubjective dimension of knowledge between men and women, and ends up not allowing the formation of the identity of the community. In other words, individual interest does not presuppose, in phenomenological terms, a common good. It depends only on a relational identity that allows the construction of a common vision of life, and not on thousands of loose individual interests.

Indeed, Keynes has addressed this problem, but this approach highlights that Keynesian solutions themselves have limitations; for example, production needs a social orientation. Aggregate consumer demand must be transformed into a demand of rights.

In this scenario, the phenomenological approach shows that capitalism works very well as it is based on individual interest; in fact, the gap in the distribution of resources increases every year. It is societies, as a collective construction, which can be considered in a crisis of rights (identity), or engulfed by the loss of meaning due to a loss of interpretation, because of the positivist logics (see Figure 7).

Finally, we can conclude that individual freedom when it is devoid of ontological elements is emptied of content and endangers the life of communities which by definition is above the individual. In this context, the attempt of this law is to try to combine individual freedom and the general interest by using the general and particular characteristics of the primary ideas. The general categories orient the system in terms of what is important, while the particular ones implement their own orientation by defining the modalities (this area is based on individual freedom). This implies that, if there are situations of scarcity, equilibrium is not obtained by increasing prices but by increasing production, because the objective is not to maintain the system in terms of prices and quantities but in terms of goods/services and needs. This means, that a good economic system is one that maintains direct coherence between the variables proposed in the law and to the capacity of workforce to change to the challenges of the time. If there are inconsistencies, there is the risk that the system becomes unbalanced and does not generate an ontological reason but only a nominal system with no relationship between economy and society. To do this, it may need a stock exchange that works with other rules. 
INSIGHTS INTO REGIONAL DEVELOPMENT

ISSN 2669-0195 (online) http://jssidoi.org/jesi/ 2020 Volume 2 Number 4 (December)

http://doi.org/10.9770/IRD.2020.2.4(5)

Figure 7. Socio-economic areas between individual freedom and community identity.

Area 1: public/State

Public economy, low level of private initiative, presence of bonding social capital
Relational identity

High level

Area 2: Social organization/meta-economics

Ontological reason and strong presence of ethical social capital
Individual freedoms

Low level
Area 4: primary economies Low levels of ethics social capital and cooperation in general
Individual freedoms

High level

Area 3: of the free market

Utilitarianism, strong law supply and demand presence based on individualist social capital, presence of bridging social capital

Relational identity

Low level 
INSIGHTS INTO REGIONAL DEVELOPMENT

ISSN 2669-0195 (online) http://jssidoi.org/jesi/

2020 Volume 2 Number 4 (December)

http://doi.org/10.9770/IRD.2020.2.4(5)

\section{References}

Bourdieu, Pierre 1980. Le capital social. Notes provisoires, Actes de la Recherche en Sciences Sociales, No 31, pp. 2-3.

Bourdieu, Pierre 1986. The forms of capital, Westport: Greenwood Press.

Braudel, Fernand 1986. I tempi della storia economica, società, civiltà, Bari: Dédalo.

Finley Moises I., 2008. L'economia degli antichi e dei moderni, Bari: Laterza.

Friedman Milton, 1953. Essays in Positive Economics, Chicago University, Chicago.

Donati Pierpaolo, Solci Riccardo, 2011. I beni relazionali. Che cosa sono e quali effetti producono, Torino: Bollati Boringhieri.

Heidegger Martin. 2011 [1927]. El ser y el tiempo, Fondo de Cultura Económica, México.

Husserl Edmund, 2008. La crisis de las ciencias europeas y la fenomenología trascendental, Buenos Aires: Prometeo.

Hirschman, A. (Ed.). (1979). Le passioni e gli interessi. Argomenti politici in favore del capitalismo prima del suo trionfo, Milán: Feltrinelli.

Hobsbawm, E. (Ed.). (2010 [1975]). La era del Capital 1848-1875, Buenos Aires: Crítica.

Husserl, Edmund, 1986. Ideas relativas a una fenomenología pura y a una filosofía fenomenológica, Fondo de Cultura Económica, México.

Kant Immanuel, 2004 [1788]. Critica della ragion pratica, Editrice Bompiani, Milano, 2004.

Kant Immanuel, 1991 [1781]. Critica della ragion pura, III Edizione, Editrice Tascabili Bompiani, Milano.

Keynes John Maynard, 2012. Teoría general de la ocupación, el interés y el dinero, Buenos Aires: Fondo de Cultura Económica.

Keynes Naville, 1884. Studies and Exercises in Formal Logic, Macmillan and Company.

Keynes Naville, 1999 [1891]. The Scope and Method of Political Economy, Batoche Book.

Polanyi Karl, 2000 [1944]. La grande trasformazione, Einaudi, Torino.

Rifking Jeremy, (1995). La fine del lavoro, il declino della forza lavoro globale e l'avvento dell'era post-mercato, Baldini\&Castoldi.

Schütz Alfred, 2003 [1962]. El problema de la realidad Social, Escritos I. Buenos Aires-Madrid: Amorrortu, Editores.

Schumpeter Joseph, 1990. Storia dell'analisi economica, Turín: Bollati Boringhieri.

Smith Adam, 2013. La Ricchezza delle Nazioni, Novara: UTET.

Stiglitz, Joseph (2010). Caída libre: El libre mercado y el hundimiento de la economía mundial, Madrid: Taurus.

Vigliarolo Francesco, 2017. Lupi e agnelli. Societá capitaliste e vie d'uscita, Milano: Jaca Book.

Vigliarolo Francesco, 2019. La economía es un fenómeno social. Principios de fenomenología económica, Buenos Aires: Eudeba.

Vigliarolo F. (2012a). Capitale sociale nella costruzione del bene comune: dal capitale sociale etico alla socializzazione dell'economia (Social Capital and the Pursuit of the Common Good: From Ethical Social Capital to the Socialization of Economy), En Revista Sociologia e Politiche sociali, 15, 1, 2012, Migration studies e capitale sociale (a cura di) M. Bertani e P. Di Nicola, Bologna: Franco Angeli Editore. pp. 123-134. DOI: 10.3280/SP2012-001007.

Vigliarolo, F. (Ed.). (2011). Le imprese recuperate. Argentina, dal crac finanziario alla socializzazione dell'economia. Reggio CalabriaMilano: Città del Sole e Altreconomia Edizioni.

Vuotto Mirta compiladora, 2006. Economía social. Precisiones conceptuales y algunas experiencias históricas, Buenos Aires: Editorial Altamira.

Walras, Léon, 1896. Estudios de Economía Social, Segunda Sección; en Vuotto, Mirta (compiladora) 2003. Economía Social, Precisiones Conceptuales y Algunas Experiencias Históricas: 17-36. Buenos Aires: Editorial Altamira.

\section{Acknowledgements}

I thank some friends and colleagues who have stimulated me, in particular prof. Sixto Jiménez Muniain, Spanish economist, for the constructive criticism and advices, as well as prof. Stefano Zamagni for encouraging me to follow along on this work path, that is, to resume the epistemological debate in economics set aside for several decades. 
INSIGHTS INTO REGIONAL DEVELOPMENT

ISSN 2669-0195 (online) http://jssidoi.org/jesi/ 2020 Volume 2 Number 4 (December)

http://doi.org/10.9770/IRD.2020.2.4(5)

Francesco VIGLIAROLO is the full Professor of Regional Economy, University of Catolica of La Plata, Argentina. He is Director of free Chair in Economics Systema and Human Right, National University of La Plata; Associate Researcher in Centre Study of Sociology of work, Economics Faculty, UBA. Research interests: relation between society and economy, social economy and recovered enterprises, local and sustentaible devolevolpment, economic phenomenology. He has published books and articles on these topics: (2019). Economy is a social phenomenon. Principles of economic phenomenology, EUDEBA, Buenos Aires; (2017). Wolves and lambs, capitalist societies and the way out, Jaka Book, Milan. ORCID ID: orcid.org/0000-0002-9667-3730

Register for an ORCID ID:

https://orcid.org/register

Make your research more visible, join the Twitter account of INSIGHTS INTO REGIONAL DEVELOPMENT:

@ IntoInsights

Copyright (C) 2020 by author(s) and VsI Entrepreneurship and Sustainability Center

This work is licensed under the Creative Commons Attribution International License (CC BY).

http://creativecommons.org/licenses/by/4.0/

(c) (i) Open Access 